\title{
Conservation value of Beeshazari Lake: an insight into diversity and abundance of wetland birds
}

\author{
Jagan Nath Adhikari ${ }^{1,2^{*}}$, Bishnu Prasad Bhattarai ${ }^{2 * *}$ and Dina Nath Dhakal ${ }^{1 * * *}$ \\ ${ }^{1}$ Department of Zoology, Birendra Multiple Campus, Tribhuvan University, Chitwan, Nepal \\ ${ }^{2}$ Central Department of Zoology, Institute of Science and Technology, Tribhuvan University, Kirtipur, \\ Kathmandu, Nepal \\ *E-mail:jnnadhikari@gmail.com ORCID ID: https://orcid.org/0000-0002-6881-6618 \\ ${ }^{* *}$ E-mail: bhattaraibp@gmail.com, ORCID ID: https://orcid.org/0000-0001-5741-6179 \\ ***E-mail:dndhakal2013@gmail.com, ORCID ID: https://orcid.org/0000-0003-1680-7127
}

\begin{abstract}
Beeshazari and associated lakes play the vital roles in providing feeding and breeding grounds for a large number of wetland fauna including many migratory birds. Wetland dependent birds in Beeshazari lake system was studied by using Area Search and Scan Sampling methods. We recorded a total of 44 wetland bird species belonging to 11 families and 9 orders. These lakes support a total of $7.5 \%$ of globally threatened and $8.93 \%$ of the nationally threatened birds. The species diversity and abundance were more in winter than in summer seasons. Fishermen and tourist pressure caused significantly negative impact on abundance and distribution of wetland birds. The major threats to wetland birds in this area were human disturbance, habitat degradation and declining water quality due to eutrophication and invasion of alien plant species such as water Hyacinth and Southern Cutgrass. Therefore, such threats need to be addressed for the long-term survival of wetland birds and extension of conservation value of Beeshazari lake system.
\end{abstract}

Key words: Bird conservation, Haliaeetus leucoryphus, Ramsar site, Eutrophication, Chitwan

DOI: http://dx.doi.org/10.3126/on.v16i1.21563

Manuscript details: Received: 02.04.2018 / Accepted: 02.08.2018

Citation: Adhikari, J.N., B.P. Bhattarai and D.N. Dhakal 2018 Conservation value of Beeshhazari Lake: an insight into diversity and abundance of wetland birds, Our Nature 16(1): 17-26. DOI: http://dx.doi.org/10.3126/on.v16i1.21563

Copyright: @ Adhikari, Bhattarai and Dhakal 2018. Creative Commons Attribution - Non Commercial 4.0 International License.

\section{Introduction}

Nepal, the Himalyan country, supports 878 species of birds $(8.78 \%$ of the global bird species) due to its landscape and topographic heterogeneity. Among them, 40 are globally threatened species, 19 near threatened species (DNPWC, 2018; IUCN, 2018). Due to habitat shrinking and invasion of alien plant species due to eutrophication in wetlands more than $27 \%$ of the wetland birds have enlisted as nationally threatened category (Grimmett et al., 2016; Inskipp et al., 2017; Birdlife International, 2018; BCN, 2018).

Wetlands play the key roles in providing feeding and breeding places for a large number of threatened fauna including birds (Parchizadeh and Williams, 2018). While the wetland birds play vital roles in many aquatic ecosystems by acting as the predators, herbivores and vectors of seeds, invertebrates and nutrients. these birds are the bio-indicators of ecological condition of water bodies and also help to control the pests (Green and Elmberg, 2014). Freshwater wetlands hold more than $40 \%$ bird species of the entire world (Inskipp et al., 2017). Wetlands of Nepal supports a total of $40(27 \%)$ of nationally threatened birds (Inskipp et al., 2016; BCN, 2018). The ecological health of the wetland is determined by the presence and absence of birds (Rajpar and Zakaria, 2010). About 6\% of total global land is covered by fresh water (Price, 2017) however, 5\% of total area of Nepal is covered by the water resources (Mandal et al., 
2017). As much as ten globally significant wetlands in Nepal are decelerated as Ramsar Sites that occupy 60,561 ha area (NLCDC, 2018). About $0.5 \%$ of the total area of Chitwan National Park is occupied by the wetlands having area more than one hector (except rivers and streams) (CNP, 2018).

Oxbow types of lakes are common in lowland Terai region of Nepal which is characterized by the deposition of water in the old tracts of rivers, streams and deep marshy lands. Beeshazari lake system is an extensive typical oxbow lake system of the inner Terai that provides an excellent habitat for many endangered fauna including many residential and migratory wetland birds as a perennial waterhole (Zhu et al., 2015). The lake systems are characterized by a mosaic of subtropical forests, grasslands, and pools of water (Bhattarai et al., 2017). This globally significant wetland is under grave threat due to a high pressure of people from two sides of BCF (eastern and western Chitwan) and tourists. Besides, these lakes have been facing serious eutrophication problems that shrink area of lakes.

Beeshazari lake system (BLS) is the major water source for many species of wildlife including resident and migratory birds. There were various formal and informal surveys of birds conducted in this area. Bird Education Society (BES) is the main local institution that has been organized bird watching activities for conservationists, school and college students to provide up to date knowledge on birds in regular basis and their latest report listed around 302 species of birds including 54 species of wetland birds in BCF (BES, 2017). Scot and Rose (1989) mentioned a total of 273 species belonging to 61 families of birds from Beeshazari lake and associated areas, in which 60 species are wetlands- dependant. The survey of birds in BCF including BLS by National Trust for Nature Conservation (NTNC) recorded 52 species of wetland birds (NTNC, 2003). Rai (2003) reported 60 wetland bird species (among 270 bird species) in Beeshazari lake and associated areas. Bhattarai (2006) reported 303 species of birds in BCF including BLS among them 54 are wetland dependent birds. Likewise, Bhattarai (2012) studied distribution, abundance and conservation of four species of storks in BCF, Khadka et al. (2017) recorded 46 species of wetland birds in and around Rapti and Narayani rivers and Lamichhane et al., (2016) found 58 species of wetland birds in bufferzone part of
BCF. These earlier studies showed lacking of focussed study of wetland dependent birds in BLS. So, this study was designed to highlight the conservation importance of Beeshazari lake system with special emphasis on diversity, abundance and conservation threats of wetland birds.

\section{Study area}

The Beeshazari and associated lakes, a Ramsar site lie in middle part of the Barandabhar Corridor Forest (BCF) an important wildlife corridor connecting the Chitwan National Park (CNP) with Mahabharat range in the north and Valmiki Tiger Reserve, India in the South. The lake system is bordered by the national EastWest Highway to the north, the Rapti River to the south, and by villages Ratnanagar Municipality to the east and Bharatpur Metropolitan city to the west (Thapa, 2011). $\mathrm{BCF}$ has a humid and subtropical monsoon climate. The mean monthly temperature varies from $15^{\circ} \mathrm{C}$ in January to $29^{\circ} \mathrm{C}$ in June and annual rain fall ranges from 1800 to $2200 \mathrm{~mm} /$ annum (NTNC, 2003; Thapa, 2011). Rapti river system in the south and Kageri river, Budi Rapti rivers, Siddhi kola and other small associates streams are the major drainage of the BCF. Globally significant lakes such as Beeshazari, Tikauli lake, Batulpokhari lake, Kumal lake, Thulo Ghol, Sano Ghol, Chepte Ghol, Gaida Ghol, Rhino lake etc provides the good shelters for wildlife (NTNC, 2003). This lake system is surrounded by seven bufferzone community forests (BZCF) (CNP, 2018). This lake system covers 3200ha area (Fig. 1) that consists of Satrahazari $\quad\left(27^{\circ} 37^{\prime} 06.3^{\prime \prime} \mathrm{N}, \quad 84^{\circ} 27^{\prime} 10.4{ }^{\prime \prime} \mathrm{E}\right)$,

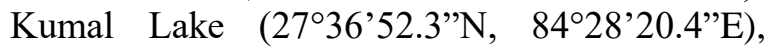
Beeshazari $\quad\left(27^{\circ} 37^{\prime} 04.6^{\prime \prime} \mathrm{N}, \quad 84^{\circ} 26^{\prime} 11.3^{\prime \prime} \mathrm{E}\right)$, Athaishazari lake $\left(27^{\circ} 36^{\prime} 38.7^{\prime \prime} \mathrm{N}, \quad 84^{\circ} 25^{\prime}\right.$ 03.2"E) and other small lakes (Bhuju et al., 2007). The Beeshazari lake system including $\mathrm{BCF}$ has been recently declared as an Important Bird and Biodiversity Areas (IBA) of Nepal (Baral and Inskipp, 2005). It contains more than 199 species of vegetation including 17 species of Graminae and 13 species of Leguminosae family (Gilani et al., 2017; Khadka et al., 2017). Sal (Shorea robusta) is the dominant tree species around Beeshhazari lake system. The most parts of the lake system are covered with aquatic vegetations such as Morning glory (Ipomea carnea), Water hyacinth (Eichhornia crassipes), Water chestnut (Trapa bispinosa), and Evening primrose (Ludwigia adscendens), Water velvet 
(Azolla imbricata), Southern Cut Grass (Leersia hexandra) Duckweed (Lemna spp.) (Bhattarai, 2012). This area is the home of several endangered or threatened fauna, including turtles, crocodiles, fishes, Dhole (Cuon alpinus), Fishing cat (Prionailurus viverrinus), Bengal Tiger (Panthera tigris tigris), One horned Rhinoceros (Rhinoceros unicornis) and several wetland dependent birds (Gilani et al., 2017; Kunwar, 2015; Baral and Inskipp, 2005).

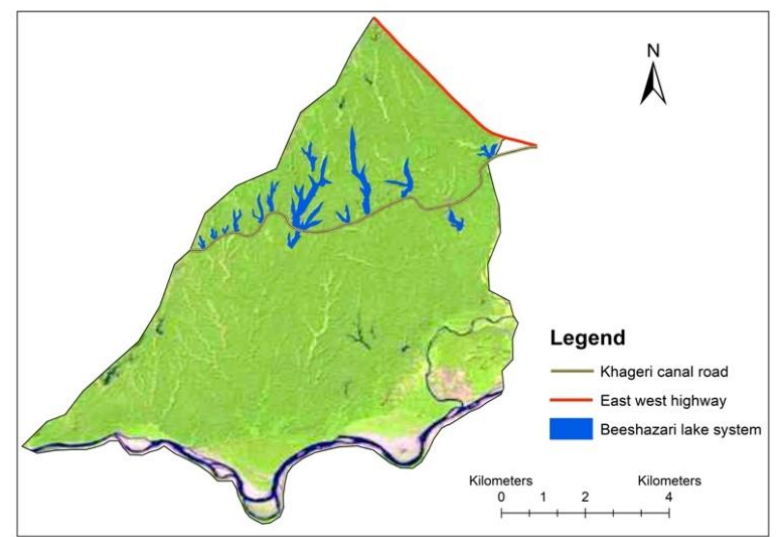

Figure 1. Location map of Beeshazari lake system: the lakes round the Khageri canal system are called Beeshazari lake system, the globally significant Ramsar site of Nepal

\section{Materials and methods Data collection}

The wetland birds were surveyed using Area Searches (AS) and Scan Sampling methods during two seasons (winter and summer) in 2017. All the lakes of Beeshazari lake system were considered as bird's hotspots areas and used for the monitoring of wetland birds (Basnet et al., 2016; Bibby et al., 2000). Direct observation method ("look-see" counting method) was used to identify and record the individuals of bird species by using binoculars (Nikon 168FT/1000YDS, 56/1000m). Unidentified species were photographed using Camera (Nikon CoolPiX B700 NIKKOR 60X) for further identification and confirmation. Birds were identified by using a bird's guide book (Shrestha, 2001; Grimmett et al., 2011, 2016). In each lake, certain points were fixed at its periphery for bird watching with the help of binoculars (Dahal et al., 2015; Jia et al., 2018). During the survey, the number of individuals, associated habitat types, human disturbance indicators such as number of tourists and number of fishermen etc. were recorded. Birds were monitored early in the morning from $6 \mathrm{AM}$ to 10
$\mathrm{AM}$ and in the evening from $4 \mathrm{PM}$ to $6 \mathrm{PM}$ (Bibby et al.,2000).

\section{Data processing and analysis}

The seasonal diversity of the wetland birds, diversity indices include Simpson's dominance and diversity, Shannon, Evenness indices, Jacob's Equitability index were determined in PAST V 3.18 (Hammer et al., 2001; Nooten et al., 2018). Further analysis was performed in SPlus. The threatened status (globally and nationally) of the birds was identified by using IUCN red list and National Redlist Data Book (NRDB) (Inskipp et al., 2016). Besides, we also used species accumulation curves to show the effectiveness of sampling and diversity of birds. Species accumulation curve is important to find out the relationship between the species and area sampled (Ugland et al., 2003). Increasing the sampling effort increases the number of species (Chao and Jost, 2012). Such effect is illustrated in a species accumulation curve, in which $\mathrm{x}$-axis is the number of individuals recorded or species abundance and $y$-axis is the number of species observed or species richness.

\section{Results and discussion Diversity of wetland birds}

A total of 913 individuals of wetland birds belonging to 44 species, 11 families and 9 orders were recorded in Beeshazari lake system in 2017. Results showed that Anseriformes had highest number of species (13 species) followed by Pelecaniformes (11 species), Coraciiformes (6 species), Gruiformes (5 species), Ciconiiformes (3 species), Suliformes (2 species), Accipitriformes (2 species) Podicipediformes (1 species) and Strigiformes (1 species) (Table 1). Earlier studies showed inconsistent number of species of birds in and around BCF. For example, Scot and Rose (1989) reported 273 species belonging to 61 families of birds from Beeshazari lake and associated areas, in which 60 species were wetlands dependant. NTNC (2003) reported 52 species of wetland birds in BCF. Likewise, Rai (2003) recorded 60 wetland bird species (among 270 bird species) in Beeshazari lake system. Bhattarai (2006) reported 303 species of birds in BCF including BLS among them 54 are wetland dependent birds. Later, Bhattarai (2012) reported four species of storks in BCF, Khadka et al. (2017) reported 46 species of wetland birds around Rapti and Narayani rivers and Lamichhane et al. 
Table1. Wetland birds in Beeshazari lake system recorded during study period.

\begin{tabular}{|c|c|c|c|c|c|}
\hline SN & Common Name & Zoological Name & Abundance & $\begin{array}{l}\text { IUCN } \\
\text { status }\end{array}$ & NRDB \\
\hline \multicolumn{6}{|c|}{ Order: Accipitriformes, Family: Accipitridae } \\
\hline 1 & Pallas's Fish Eagle & Haliaeetus leucoryphus Pallas, 1771 & 1 & EN & $\mathrm{CR}$ \\
\hline 2 & Grey-headed Fish Eagle & Icthyophaga ichthyaetus Horsfield, 1821 & 3 & NT & $\mathrm{CR}$ \\
\hline \multicolumn{6}{|c|}{ Order: Anseriformes, Family: Anatidae } \\
\hline 3 & Northern Pintail & Anas acuta Linnaeus, 1758 & 29 & $\mathrm{LC}$ & EN \\
\hline 4 & Common Teal & Anas crecca Linnaeus, 1758 & 34 & $\mathrm{LC}$ & $\mathrm{LC}$ \\
\hline 5 & Mallard & Anas platyrhynchos Linnaeus, 1758 & 9 & $\mathrm{LC}$ & $\mathrm{LC}$ \\
\hline 6 & Indian Spot-billed Duck & Anas poecilorhyncha Linnaeus, 1758 & 21 & $\mathrm{LC}$ & NT \\
\hline 7 & Gadwall & Anas strepera Forster, 1781 & 15 & $\mathrm{LC}$ & $\mathrm{LC}$ \\
\hline 8 & Lesser Whistling-duck & Dendrocygna javanica Horsfield, 1821 & 18 & $\mathrm{LC}$ & $\mathrm{LC}$ \\
\hline 9 & Little Pratincole & Glareola lactea Temminck, 1820 & 15 & $\mathrm{LC}$ & NT \\
\hline 10 & Pheasant-tailed Jacana & Hydrophasianus chirurgus Scopoli, 1786 & 20 & $\mathrm{LC}$ & VU \\
\hline 11 & Goosander & Mergus merganser Linnaeus, 1758 & 22 & $\mathrm{LC}$ & $\mathrm{LC}$ \\
\hline 12 & Bronze-winged Jacana & Metopidius indicus Latham, 1790 & 12 & $\mathrm{LC}$ & $\mathrm{LC}$ \\
\hline 13 & Cotton Pygmy-goose & Nettapus coromandelianus Gmelin, 1789 & 12 & $\mathrm{LC}$ & VU \\
\hline 14 & Red-wattled Lapwing & Vanellus indicus Boddaert, 1783 & 9 & $\mathrm{LC}$ & $\mathrm{LC}$ \\
\hline 15 & Yellow-wattled Lapwing & Vanellus malabaricus Boddaert, 1783 & 24 & $\mathrm{LC}$ & VU \\
\hline \multicolumn{6}{|c|}{ Order: Ciconiiformes, Family: Ciconiidae } \\
\hline 16 & Asian Openbill Stork & Anastomus oscitans Boddaert, 1783 & 58 & $\mathrm{LC}$ & VU \\
\hline 17 & Asian Woollyneck Stork & Ciconia episcopus Boddaert, 1783 & 3 & VU & NT \\
\hline 18 & Lesser Adjuntant Stork & Leptoptilos javanicus Horsfield, 1821 & 26 & VU & VU \\
\hline \multicolumn{6}{|c|}{ Order: Coraciiformes, Family: Alcedinidae } \\
\hline 19 & Common Kingfisher & Alcedo atthis Linnaeus, 1758 & 25 & $\mathrm{LC}$ & $\mathrm{LC}$ \\
\hline 20 & Blue-eared Kingfisher & Alcedo meninting Horsfield, 1821 & 22 & $\mathrm{LC}$ & EN \\
\hline 21 & Pied Kingfisher & Ceryle rudis Linnaeus, 1758 & 3 & $\mathrm{LC}$ & $\mathrm{LC}$ \\
\hline 22 & Black-capped Kingfisher & Halcyon pileata Boddaert, 1783 & 5 & $\mathrm{LC}$ & $\mathrm{LC}$ \\
\hline 23 & White-breasted Kingfisher & Halcyon smyrnensis Linnaeus, 1758 & 16 & $\mathrm{LC}$ & $\mathrm{LC}$ \\
\hline 24 & Stork-billed Kingfisher & Pelargopsis capensis Linnaeus, 1766 & 3 & $\mathrm{LC}$ & $\mathrm{LC}$ \\
\hline \multicolumn{6}{|c|}{ Order: Gruiformes, Family: Rallidae } \\
\hline 25 & Brown Crake & Zapornia akool Sykes, 1832 & 16 & $\mathrm{LC}$ & $\mathrm{LC}$ \\
\hline 26 & White-breasted Waterhen & Amaurornis phoenicurus Pennant, 1769 & 60 & $\mathrm{LC}$ & $\mathrm{LC}$ \\
\hline 27 & Common Coot & Fulica atra Linnaeus, 1758 & 13 & $\mathrm{LC}$ & $\mathrm{LC}$ \\
\hline 28 & Purple Swamphen & Porphyrio porphyrio Linnaeus, 1758 & 33 & $\mathrm{LC}$ & $\mathrm{LC}$ \\
\hline 29 & Ruddy-breasted Crake & Porzana fuscaLinnaeus, 1766 & 27 & $\mathrm{LC}$ & $\mathrm{LC}$ \\
\hline \multicolumn{6}{|c|}{ Order: Pelecaniformes, Family:Ardeidae } \\
\hline 30 & Grey Heron & Ardea cinerea Linnaeus, 1758 & 7 & $\mathrm{LC}$ & $\mathrm{LC}$ \\
\hline 31 & Intermediate Egret & Ardea intermedia Wagler, 1829 & 18 & $\mathrm{LC}$ & $\mathrm{LC}$ \\
\hline 32 & Purple Heron & Ardea purpurea Linnaeus, 1766 & 6 & $\mathrm{LC}$ & $\mathrm{LC}$ \\
\hline 33 & Indian Pond Heron & Ardeola grayii Sykes, 1832 & 31 & $\mathrm{LC}$ & $\mathrm{LC}$ \\
\hline 34 & Green-backed Heron & Butorides striatus Linnaeus, 1758 & 63 & $\mathrm{LC}$ & $\mathrm{LC}$ \\
\hline 35 & Great White Egret & Casmerodius albus Linnaeus, 1758 & 16 & $\mathrm{LC}$ & $\mathrm{LC}$ \\
\hline 36 & Little Egret & Egretta garzetta Linnaeus, 1766 & 100 & $\mathrm{LC}$ & $\mathrm{LC}$ \\
\hline 37 & Cinnamon Bittern & Ixobrychus cinnamomeus Gmelin, 1789 & 6 & $\mathrm{LC}$ & $\mathrm{LC}$ \\
\hline 38 & Yellow Bittern & Ixobrychus sinensis Gmelin, 1789 & 8 & $\mathrm{LC}$ & $\mathrm{LC}$ \\
\hline 39 & Black-crowned Night Heron & Nycticorax nycticorax Linnaeus, 1758 & 30 & $\mathrm{LC}$ & $\mathrm{LC}$ \\
\hline \multicolumn{6}{|c|}{ Order: Pelecaniformes, Family:Threskiornithidae } \\
\hline 40 & Black Ibis & Pseudibis papillosa Temminck, 1824 & 3 & $\mathrm{LC}$ & $\mathrm{LC}$ \\
\hline \multicolumn{6}{|c|}{ Order: Podicipediformes, Family: Podicipedidae } \\
\hline 41 & Black-necked Grebe & Podiceps nigricollis Brehm, 1831 & 12 & $\mathrm{LC}$ & $\mathrm{LC}$ \\
\hline \multicolumn{6}{|c|}{ Order: Strigiformes, Family: Strigidae } \\
\hline 42 & Brown Fish Owl & Ketupa zeylonensisGmelin, 1788 & 8 & $\mathrm{LC}$ & VU \\
\hline \multicolumn{6}{|c|}{ Order: Suliformes, Family: Anhingidae } \\
\hline 43 & Oriental Darter & Anhinga melanogaster Pennant, 1769 & 12 & NT & NT \\
\hline \multicolumn{6}{|c|}{ Family: Phalacrocoracidae } \\
\hline 44 & Great Cormorant & Phalacrocorax carbo Linnaeus, 1758 & 39 & $\mathrm{LC}$ & NT \\
\hline
\end{tabular}


(2016) reported 58 species of wetland birds in buffer zone part of BCF. There were also various such studies conducted in the wetlands of other parts of Nepal such as 77 bird species in Jagadishpur reservoir (Thapa and Saund, 2012), 39 species in Phewa lake (Giri and Chalise, 2008) and 36 species of wetland birds in Rupa lake (Kafle et al., 2008). Similarly, Chhetry (2006) reported 98 species of wetland birds belonging to 60 genera and 18 families around the Koshi barrage area. Similar study in Suklaphanta National Park found a total of 15 globally threatened and 13 near-threatened bird species where majority of the birds were the wetland dependent birds (Baral and Inskipp, 2009). It indicates that Beeshazari lake system alone supported more species of wetland birds than Rupa, Phewa lake and lower than Jagadishpur reservoir, Koshi barrage and Rapti and Narayani river systems. Therefore, this area including CNP and Buffer zone areas are declared as an Important Bird and Biodiversity Areas (IBBA) of Nepal because of high conservation value (Baral and Inskipp, 2005).

The diversity of the wetland bird was higher during winter (Shannon's index of diversity $H=3.423$, Simpson index $1-D=0.96$, Jacob's equitability $J=0.921$, evenness $=0.747$ ) than summer season $(H=2.91,1-D=0.92, J=0.893$, evenness $=0.706)$. Species dominance index was found higher in summer $(D=0.0723)$ than in winter $(D=0.0399)$ (Table 2). Diversity profile curve of wetland birds at $95 \%$ confidence interval showed significantly $(F=3.811$, $d f=85.74, p=0.05$ ) higher diversity in winter as compared to summer (Fig. 2). Similar type of study conducted in Phewa lake found higher diversity of birds in winter $(H=2.6228)$ than in summer $(H=1.2014)$ (Giri and Chalise, 2008) and research conducted in Mangala Dam, India found the species diversity of wetland birds was more in winter $(H=3.31)$ than summer $(H=2.29)$ (Khan and Ali, 2014).

The species accumulation curve of wetland birds in winter season is exponentially increased up to 225 and very slowly increase up to 562 while in summer season the curve shows exponential increase up to 100 and then very slowly increase up to 350 (Fig. 3). These all analysis shows the higher diversity of wetland birds during winter season in Beeshazari and associated lakes. Occurrence of such patterns was mainly due to a large number of winter visitor birds compared to summer visitors in this area. The species accumulation curve continues to rise as more individuals are sampled, then the curve become shallower because the rare species are very rarely encountered, hence more sampling effort is required to get all species present in sampled area (Colwell et al., 2004).

Table 2. Wetland bird's species diversity and dominance indices in BCF.

\begin{tabular}{lrrr}
\hline Category & \multicolumn{1}{c}{ Total } & Winter & Summer \\
\hline Species richness & 44 & 41 & 26 \\
Abundance & 913 & 563 & 350 \\
Dominance_D & 0.04188 & 0.03997 & 0.07236 \\
Simpson_1-D & 0.9581 & 0.96 & 0.9276 \\
Shannon_H & 3.442 & 3.423 & 2.91 \\
Evenness_e^H/S & 0.7105 & 0.7476 & 0.7062 \\
Equitability_J & 0.9097 & 0.9217 & 0.8932 \\
\hline
\end{tabular}

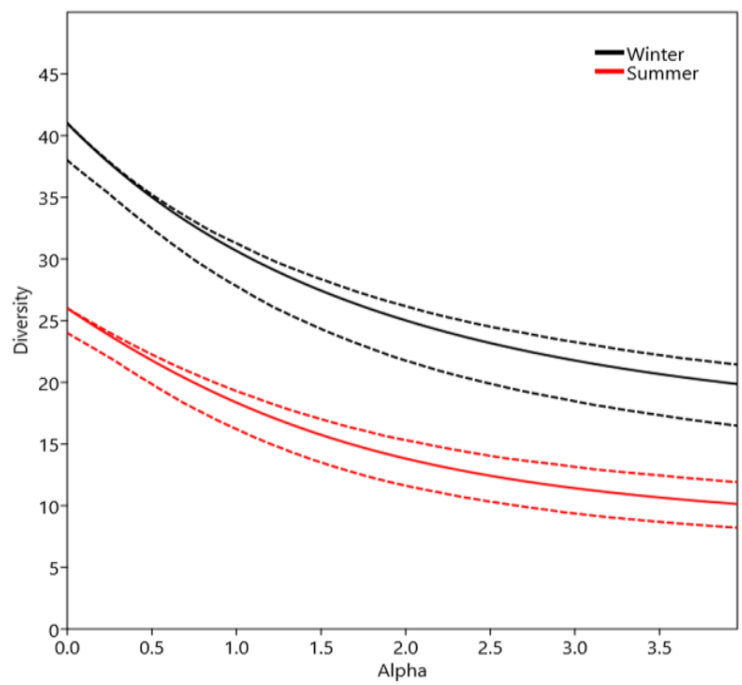

Figure 2. Species diversity profiles of wetland birds in Beeshazari lake system at $95 \%$ confidence interval (dotted lines).

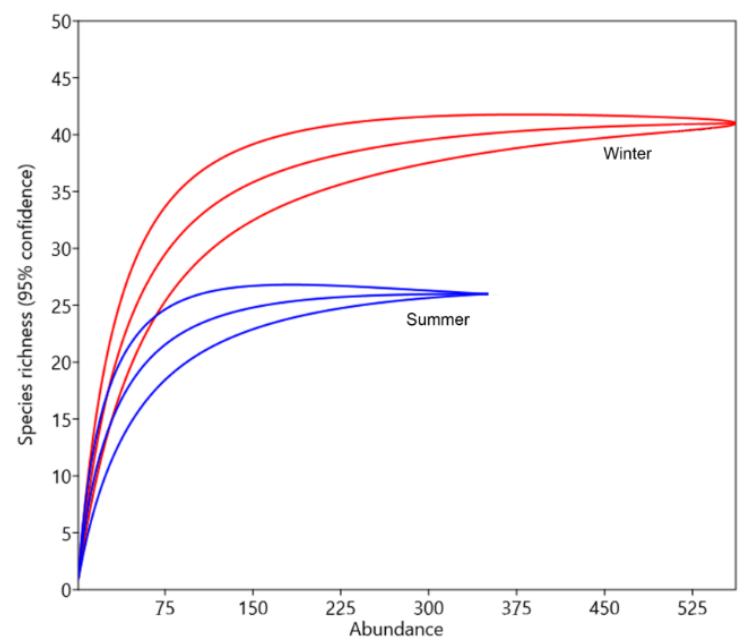

Figure 3. Species accumulation curves for summer and winter seasons (comparing species richness between two seasons- summer and winter). For both seasons, the middle line shows the individual rarefaction and upper and lower lines show $95 \%$ confidence limit. 
Conservation value of Beeshazari and associated lakes

Beeshazari lake system supports $7.5 \%$ of globally threatened birds (40 species) and $8.93 \%$ of nationally threatened birds (15 out of 168 nationally threatened birds) in National Red Data Book (NRDB) (Inskipp et al., 2016). This study recorded three globally vulnerable wetland birds (Pallas's Fish Eagle Haliaeetus leucoryphus, Lesser Adjutant Stork Leptoptilos javanicusFig. 4, Asian Woollyneck Stork Ciconia episcopus) and two globally near threatened birds (Grey-headed Fish Eagle Icthyophaga ichthyaetus- Fig. 5, Oriental Darter Anhinga melanogaster- Fig. 6) (BCN and DNPWC, 2011; Bhattarai, 2012). Among the nationally threatened birds (15), two are critically endangered (Pallas's Fish Eagle and Grey-headed Fish Eagle), two are endangered (Northern Pintail Anas acuta, Blue-eared Kingfisher Alcedo meninting, six are vulnerable (Pheasanttailed jacana Hydrophasianus chirurgus, Cotton Pigmy-goose Nettapus coromandelianus, Yellow-wattled Lapwing Vanellus malabaricus, Asian Openbill Stork Anastomus oscitans, Lesser Adjutant Stork Leptoptilos javanicus, Brown Fish Owl Ketupa zeylonensis) and five are near threatened (Indian Spot-billed Duck Anas poecilorhyncha Little Pratincole Glareola lactea Woolly-necked Stork Ciconia episcopus Oriental Darter Anhinga melanogaster, Great Cormorant Phalacrocorax carbo) (Inskipp et al., 2016) (Fig. 7; Table 1). Sharma (2004) recorded twelve nationally threatened birds in BCF. NTNC (2015) also highlighted the conservation importance of this lake system due to its rich ecosystem services to wildlife and people. Inskipp et al. (2016) described 167 nationally threatened birds including 67 Critically Endangered, 38 Endangered and 62 Vulnerable species. Since then Red-faced Liocichla Liocichla phoenicea was found in Nepal and was assessed as Critically Endangered, so the number of nationally Critically Endangered species is now 68 and there are 168 nationally threatened species (Inskipp et al., 2017).

The major threats to wetland birds are fishing, livestock grazing and human disturbances in most of wetland areas of Chitwan. However, livestock grazing is not common as it is prohibited in and around Beeshazari lake areas. Besides, fishing practices (e.g. fishes, snails) are more common in associated lakes of Beeshazari lake and other small ponds. Tourists (both local and foreign) pressure was found the most common in Beeshazari lake area. Our results showed the negative relationship (Fig. $8 ; y=-0.427 x+4.723$, $\left.R^{2}=0.058, F=3.591, P=0.0001\right)$ between number of fisherman (Fig. 9) and abundance wetland birds. The number of tourists present in and around the Beeshazari lake system showed significantly negative impact on the abundance of wetland birds (Fig. 10; $y=-0.261 x+5.382, R^{2}$ $=0.127, F=2.535, P=0.002)$. The study of wetland birds in Yangtze river found human disturbance, habitat loss, eutrophication and pollution are the major drivers of distribution and abundance of wetland birds (Jia et al., 2018). Many migratory wetland birds are threatened due to destruction and degradation of wetlands in Nepal and abroad (Lamsal et al., 2018; Prusty et al.,2017; Szabo and Mundkur, 2017). Similar type of problems such as methane formation in wetlands, impact of eutrophication and a huge colonization of invasive alien plant species (e.g., Water Hyacinth and Southern Cut Grass- Fig. 11) were highly common in Beeshazari lake system (e.g., depleted Sorahazar Satrahazar, Athaishazar lakes) (Zhu et al., 2015; Mandal et al., 2017).

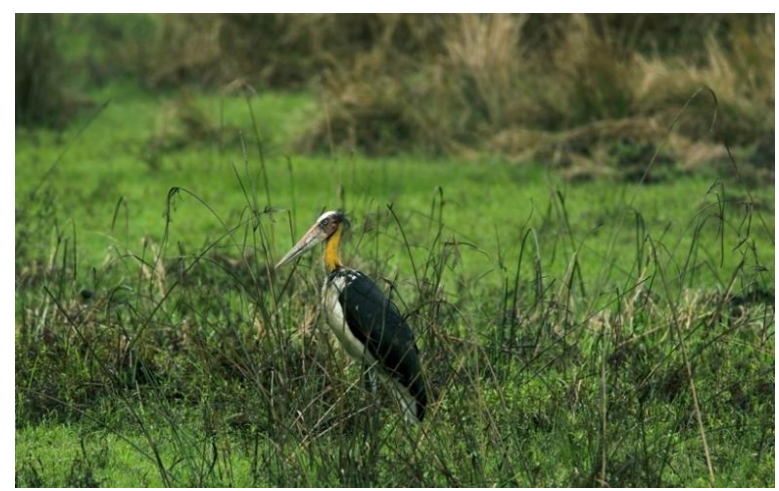

Figure 4. Lesser adjutant stork Leptoptilos javanicus near Kumal Lake.

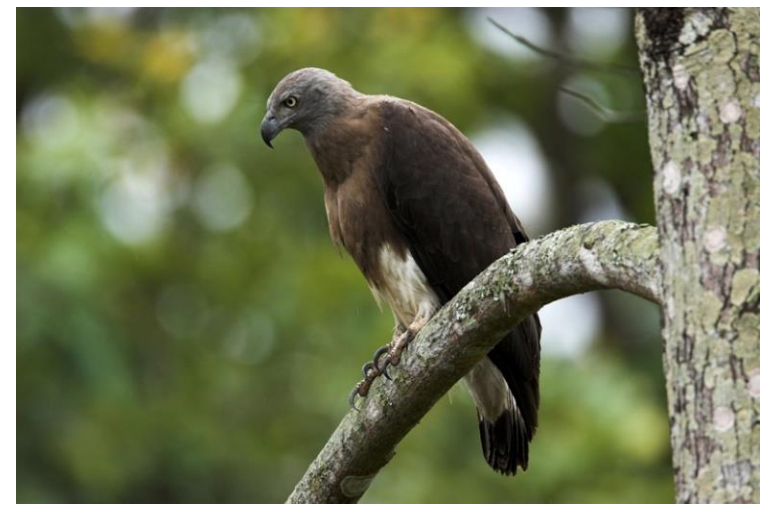

Figure 5. Grey-headed Fish Eagle Icthyophaga ichthyaetus near Satrahazari lake area. 


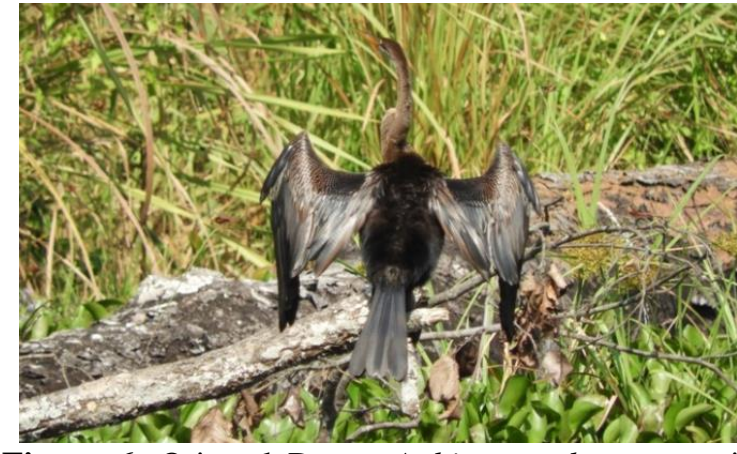

Figure 6. Oriental Darter Anhinga melanogaster in Athaishazari lake.

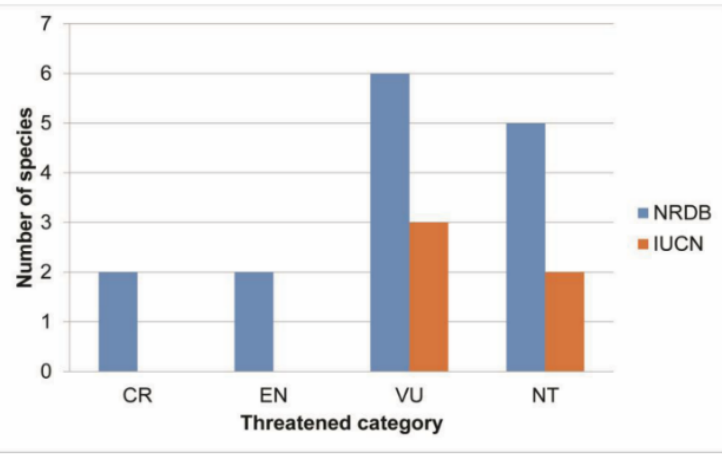

Figure 7. Threatened wetland birds recorded in Beeshazari lake system $(\mathrm{CR}=$ Critically endangered, $\mathrm{EN}=$ Endangered, $\mathrm{VU}=$ Vulnerable, $\mathrm{NT}=\mathrm{Near}$ threatened, NRDB $=$ Nepal Red Data Book)

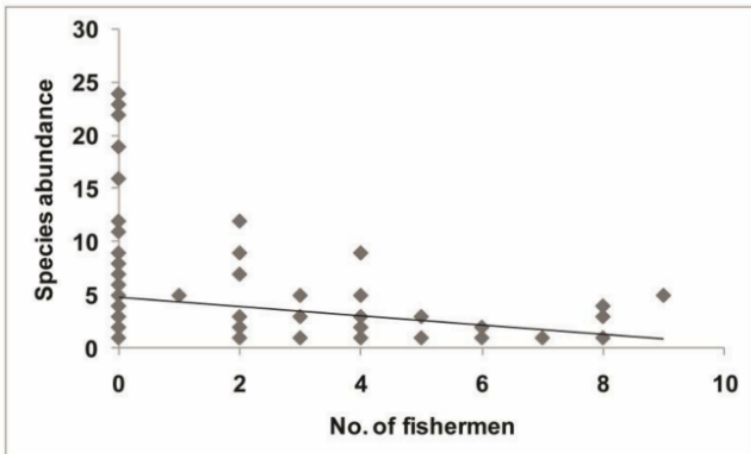

Figure 8. Effect of fishermen on the occurrence and abundance of wetland birds in Beeshazari lake system $\left(y=-0.427 x+4.723, \quad R^{2}=0.058, \quad F=3.591\right.$, $P=0.0001)$

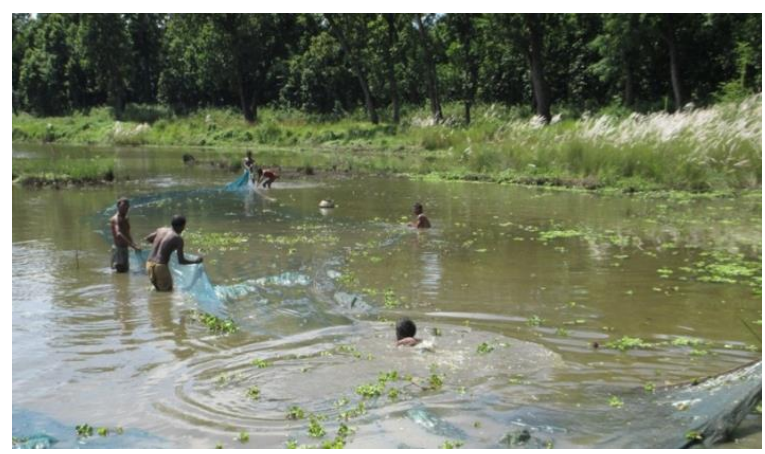

Figure 9. Fishing practices are another great threat to wetland birds in the Beeshazari lake system.

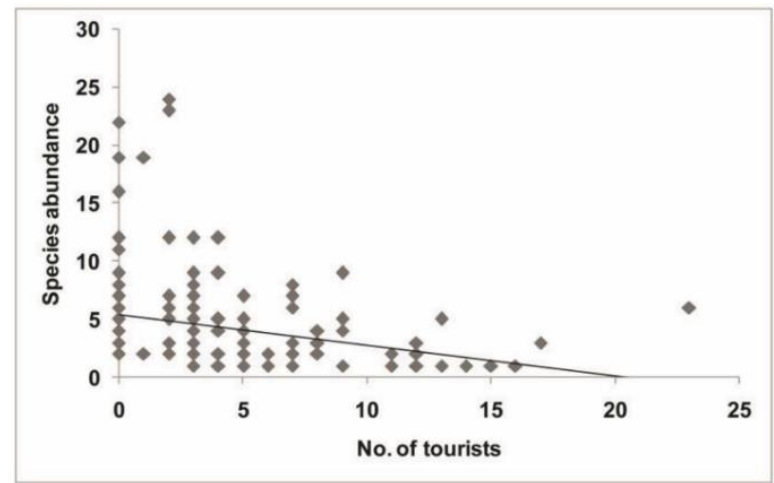

Figure 10. Effect of tourist pressure on the occurrence and abundance of wetland birds in Beeshazari lake system $\left(y=-0.261 x+5.382, R^{2}=0.127, F=2.535, P\right.$ $=0.002)$.

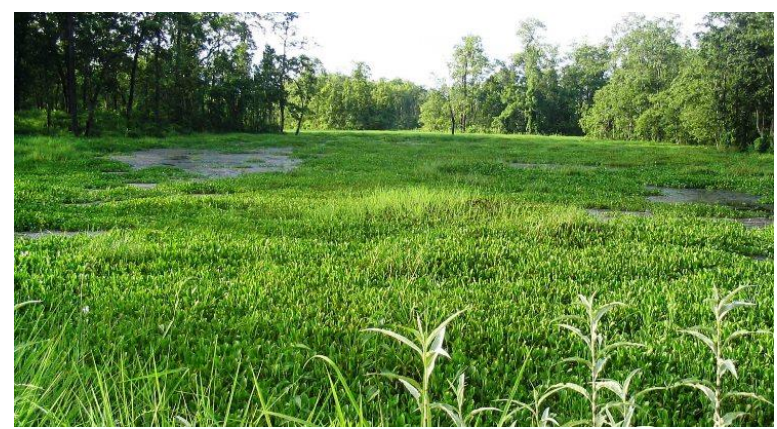

Figure 11. Dense mat of invasive alien species Southern Cut Grass Leersia hexandra and water hyacinth Eichhornia crassipes: Problem of eutrophication in Beeshazari and associated lakes.

\section{Conclusion}

Conservation importance of Beeshazari lake system was assessed with regards to diversity and abundance of wetland birds including the impacts of threats. Present study recorded 44 species of wetland dependent birds belonging to 11 families and 9 orders. The order Anseriformes had the highest number of species (13 species) while Podicipediformes (1 species) and Strigiformes (1 species) had the least number of species. Beeshazari lake system supports a total of $7.5 \%$ of globally threatened and $8.93 \%$ of the nationally threatened birds. The species diversity of wetland birds was high in winter $(H=3.423)$ than in summer season $(H=2.91)$. However, the species dominance was lower in winter $(D=0.0399)$ than summer $(D=$ 0.072 ) indicate more diversity of wetland birds in winter than in summer season. Fishermen $\left(R^{2}\right.$ $=0.058, P=0.0001)$ and tourist pressure $\left(R^{2}=\right.$ $0.127, P=0.002$ ) caused significantly negative impacts on the occurrence and abundance of wetland birds. Besides, eutrophication caused introduction of invasive alien plant species are other major conservation problems that have 
been deteriorating the quality and quantity of water in these lakes. Furthermore, this lake system not only provides ecosystem services to the wetland dependent fauna but also a principal water source for irrigation of large area of farmlands in western Chitwan. These empirical findings show high conservation value of Beeshazari and associated lakes that need urgent conservation and management attention for respected stakeholders and general public of eastern and western Chitwan.

\section{Acknowledgements}

We would like to thank Department of National Parks and Wildlife Conservation (DNPWC) and Chitwan National Park (CNP) for granting permission to conduct this research in Beeshazari lake system. Our sincere thanks also go to the Himalayan Environment and Public Health Network (HEPHN) for providing human resources, equipments and technical supports.

\section{Author's contribution}

Jagan Nath Adhikari and Dina Nath Dhakal worked in research design and data collection. Bishnu Prasad Bhattarai worked in research design, data collection and analysis and manuscript preparation.

\section{References}

Baral, H.S. and C. Inskipp 2005. Important bird areas in Nepal: Key sites for conservation. Bird Conservation Nepal and Birdlife International, Kathmandu and Cambridge.

Baral, H.S. and C. Inskipp 2009. The birds of Sukla Phanta Wildlife Reserve, Nepal. Our Nature 7(1): 56-81.

Basnet, T.B., M.B. Rokaya, B.P. Bhattarai and Z. Münzbergová 2016. Heterogeneous landscapes on steep slopes at low altitudes as hotspots of bird diversity in a Hilly region of Nepal in the Central Himalayas. PloS one 11(3): e 0150498.

BCN 2018. National wetland bird survey 2018. Bird Conservation Nepal and Wetland International.

BCN and DNPWC 2011. The state of Nepal's birds 2010. Bird conservation of Nepal and Department of National Parks and Wildlife Conservation, Kathmandu, Nepal. ISBN: 9789937-2-3359-0.

BES 2017. Birds of Barandabhar corridor forest. An official record of Bird Education Society (BES), Sauraha, Chitwan, Nepal. www.besnepal.org

Bhattarai, B.P. 2006. Birds of Barandabhar corridor forest (Final project report). Tiger
Rhino Conservation Society (TRCS), Bharatpur, Chitwan, Nepal. 19p.

Bhattarai, B.P. 2012. Distribution and diversity of storks in the adjoining areas of Chitwan National Park, Nepal. In Himalayan Biodiversity in the Changing World (Kindlmann, P. Ed.). Springer, Dordrecht, pp. 97-114.

Bhattarai, S., C. Pokheral, B. Lamichhane and N. Subedi 2017. Herpetofauna of a Ramsar site: Beeshazari and associated Lakes, Chitwan National Park, Nepal. IRCF Reptiles and Amphibians 24(1): 17-29.

Bhuju, U.R., P.R. Shakya, T.B. Basnet and S. Shrestha 2007. Nepal biodiversity resource book: Protected areas, Ramsar sites, and World heritage sites. International Centre for Integrated Mountain Development (ICIMOD), Kathmandu, Nepal.

Bibby, C.J., N. Burgess, D. Hill and S. Mustoe 2000. Bird census techniques. Elsevier, 302p.

Birdlife International 2018. Status of Nepal's Birds. Birdlife International, UK. www.birdlife.org. (Retrieved on 15 June, 2018).

Chao, A. and L. Jost 2012. Coverage based rarefaction and extrapolation: Standardizing samples by completeness rather than size. Ecology 93(12): 2533-2547.

Chhetry, D.T. 2006. Diversity of wetland birds around the Koshi Barrage area. Our Nature 4: 91-95.

CNP 2018. Biodiversity of Chitwan National Park. http://chitwannationalparkgovnp/indexphp/biodi versity (Accessed on 17 February, 2018).

Colwell, R.K., C.X. Mao and J. Chang 2004. Interpolating, extrapolating, and comparing incidence-based species accumulation curves. Ecology 85(10): 2717-2727.

Dahal, B.R., C.A. McAlpine and M. Maron 2015. Impacts of extractive forest uses on bird assemblages vary with landscape context in lowland Nepal. Biological Conservation 186: 167-175.

DNPWC 2018. Department of National Parks and Wildlife Conservation, Nepal. Web: http://dnpwcgovnp/ (Accessed on 19 February, 2018)

Gilani, H., F.M. Qamer, M. Sohail, K. Uddin, A. Jain and W. Ning 2017. Review of ecosystem monitoring in Nepal and evolving earth observation technologies land cover change and its eco-environmental responses in Nepal. Springer. pp 165-183.

Giri, B. and M.K. Chalise 2008. Seasonal diversity and population status of water birds in Phewa lake, Pokhara, Nepal. Journal of Wetlands Ecology 1(1): 3-7. 
Green, A.J. and J. Elmberg 2014. Ecosystem services provided by waterbirds. Biological Review 89(1): 105-122.

Grimmett, R., C. Inskipp, T. Inskipp and H.S. Baral 2016. Birds of Nepal: Revised edition. Bloomsbury Publishing.

Grimmett, R., R. Inskipp and T. Inskipp 2011. Birds of the Indian Subcontinent. Oxford University Press, 528p.

Hammer, Ø., D. Harper and P. Ryan 2001. PASTPalaeontological statistics. www.uv.es/ pardomv/pe/2001_1/past/pastprog/past. 25(07): 2009.

Inskipp, C., H.S. Baral, S. Phuyal, T.R. Bhatt, M. Khatiwada, T. Inskipp, A. Khatiwada, S. Gurung, P.B. Singh, L. Murray, L. Poudyal and R. Amin 2016. The status of Nepal's birds: The national red list series. Zoological Society of London, UK. https://www.zsl.org/conservation/regions/asia/n ational-red-list-of-nepals-birds.

Inskipp, C., H.S. Baral, T. Inskipp, A.P. Khatiwada, M.P. Khatiwada, L.P. Poudyal and R. Amin 2017. Nepal's National red list of birds. Journal of Threatened Taxa 9(1): 97009722.

IUCN 2018. The IUCN red list of threatened species. Version 2017-3 <wwwiucnredlistorg> Downloaded on 24 February 2018.

Jia, Q., X. Wang, Y. Zhang, L. Cao and A.D. Fox 2018. Drivers of waterbird communities and their declines on Yangtze River floodplain lakes. Biological Conservation 218: 240-246.

Kafle, G., M. Cotton, J.R. Chaudhary, H. Pariyar, H. Adhikari, S.B. Bohora and B. Regmi 2008. Status of and threats to waterbirds of Rupa Lake, Pokhara, Nepal. Journal of Wetlands Ecology 1(1): 9-12.

Khadka, B.B., P.M. Acharya and S.L. Rajbhandari 2017. Population status and species diversity of wetland birds in the Rapti and Narayani rivers and associated wetlands of Chitwan National Park, Nepal. Journal of Threatened Taxa 9(6): 10297-10306.

Khan, B. and Z. Ali 2014. Assessment of birds'fauna, occurrence status, diversity indices and ecological threats at Mangla dam, ajk from 2011 to 2014. Journal of Animal and Plant Science 25(3): 397-403.

Kunwar, D.C. 2015. Floodplain succession pattern in Khorsor region of Budhi Rapti River, Barandabhar corridor, Chitwan, Nepal. Central Department of Botany, Tribhuvan University Kirtipur, Kathmandu, Nepal. (M.Sc. Thesis).

Lamichhane, S., R.C. Kandel, C.P. Pokheral, T.P. Dahal and S. Bhattarai 2016. Biodiversity profile of Beeshazari and associated lakes,
Chitwan. Department of National Parks and Wildlife Conservation and National Trust for Nature Conservation. 50p.

Lamsal, P., L. Kumar, A. Aryal and K. Atreya 2018. Invasive alien plant species dynamics in the Himalayan region under climate change. Ambio DOI: 10.1007/s13280-018-1017-z.

Mandal, R.A., P. Jha, N. Krakaue, A. Jha and T. Lakhankar 2017. Assessing cost effective management options of Eichhornia crassipes in ecotourism Ramsar sites, Nepal. International Journal of Agricultural Science, Research and Technology in Extension and Education Systems 7(2): 79-83.

NLCDC 2018. Ramsar sites of Nepal. National Lake Conservation and Development Committee.

http://nepallakegovnp/2017/05/01/ramsar-sitesof-nepal/ down loaded on: 24 February, 2018.

Nooten, S.S., P. Schultheiss, J. Wright, C. Macdonald, B.K. Singh, J.M. Cook and S.A. Power 2018. What shapes plant and animal diversity on urban golf courses? Urban Ecosystem. DOI: 10.1007/s11252-017-0728-4. 20.

NTNC 2003. Ecological assessment of Barandabhar forest corridor (final Report). NTNC/ Biodiversity Conservation Centre, Tiger Rhino Conservation Project. 129p.

NTNC 2015. Assessment of ecosystem services provided by Beeshazari and associated Lakes. National Trust for Nature Conservation, Sauraha Chitwan.

Parchizadeh, J. and S.T. Williams 2018. Waterbirds targeted in Iran's wetlands. Science 359(6378): 877-878.

Price, M.F. 2017. Managing MIDAs: Harmonizing the management of multi-Internationally designated areas-Ramsar sites, World Heritage sites, Biosphere reserves and UNESCO Global geoparks. Mountain Research and Developemnt 37(3): 384-384.

Prusty, B.A.K., R. Chandra and P. Azeez 2017. Wetland science: Perspectives from South Asia. Springer India. 587p. ISBN 978-81-322-3715-0. DOI: $10.1007 / 978-81-322-3715-0$

Rai, H.C. 2003. Preparation of Wildlife checklist and conduction of conservation awareness programme in the Beeshazari Tal and its suburbs, Chitwan, Nepal. A report submitted to Bird Conservation Nepal, Kathmandu, Nepal.

Rajpar, M. and M. Zakaria 2010. Indah wetland reserve, Selangor Peninsular Malaysia. Journal of Biological Sciences 10(7): 658-666.

Scott, D.A. and P.M. Rose 1989. Asian waterfowl 1989. IWRB Slimbridge, UK. 
Sharma, H.K. 2004. Diversity of threatened birds and their conservation threats in Barandabhar corridor forest, Chitwan. Central Department of Zoology, Tribhuvan University Nepal. (M.Sc. Thesis)

Shrestha, T.K. 2001. Birds of Nepal, Volume 2: Field ecology, natural history and conservation: Compact Handbook. Binita Shreatha Publication. 412p.

Szabo, J.K. and T. Mundkur 2017. Conserving wetlands for migratory water birds in South Asia. In Wetland Science: Perspectives from South Asia (Prusty, B.A.K., R. Chandra and P. Azeez Eds.). Springer India. pp 105-127.

Thapa, J.B. and T.B. Saund 2012. Water quality parameters and bird diversity in Jagdishpur Reservoir, Nepal. Nepal Journal of Science and Technology 13(1): 143-155.
Thapa, T.B. 2011. Habitat suitability evaluation for Leopard (Panthera pardus) using remote sensing and GIS in and around Chitwan National Park, Nepal. Faculty of Wildlife Sciences, Wildlife Institute of India, Dehradun and Department of Biosciences, Saurashtra University, Rajkot, Gujrat, India. (Ph.D. Thesis) Ugland, K.I., J.S. Gray and K.E. Ellingsen 2003. The species-accumulation curve and estimation of species richness. Journal of Animal Ecology 72(5): 888-897.

Zhu, D., N. Wu, N. Bhattarai, K.P. Oli, K. Tsering, G.S. Rawat, H. Chen, G. Yang, Y. He, S. Joshi, P. Rana and M. Ismail 2015. A comparative study of daytime-based methane emission from two wetlands of Nepal Himalaya. Atmospheric Environment 106:196-203. 